\title{
FIGHTING POVERTY IN NIGERIA USING THE LIBYAN EXPERIENCE DURING THE ERA OF MUAMMAR GADDAFI
}

\author{
Dr. Amangwai Josiah Monday ${ }^{1}$ and Dr. Amos Nklekerem² \\ ${ }^{1}$ Bursary Department, Federal University of Lafia, Lafia, Nasarawa State, Nigeria \\ ${ }^{2}$ Department of Political Science and International Relations, University of Abuja, Nigeria
}

Cite this article:

Amangwai J.M., Amos N. (2021), Fighting Poverty in Nigeria Using the Libyan Experience During the Era of Muammar Gaddafi. African Journal of Economics and Sustainable Development 4(2), 119-128. DOI: 10.52589/AJESD-

YTCR40RT.

\section{Manuscript History}

Received: 6 July 2021

Accepted: 12 Aug 2021

Published: 5 Sept 2021

Copyright $\odot 2020$ The Author(s). This is an Open Access article distributed under the terms of Creative Commons Attribution-NonCommercialNoDerivatives 4.0 International (CC BY-NC-ND 4.0), which permits anyone to share, use, reproduce and redistribute in any medium, provided the original author and source are credited.
ABSTRACT: This paper discusses the concept of poverty and relates it to Nigerian situation and looks at various poverty reduction strategies by successive governments in Nigeria and agrees that such strategies did not yield the desired results as more than half of the country's population still wallows in poverty. The paper looks at the experience of the Libyan government under the administration of Muammar Gaddafi in fighting poverty as an example that can be replicated in fighting poverty in Nigeria. The paper concludes by recommending ways in which the Nigerian Government can adopt in tackling poverty in the country.

KEYWORDS: Fighting Poverty, Libyan Experience, Poverty Reduction Strategies, Muammar Gaddafi 


\section{INTRODUCTION}

Poverty is a global phenomenon which affects continents, nations and people differently. It afflicts people in various depths and levels at different times and phases of existence. There is no nation that is absolutely free from poverty. The main difference is the intensity and prevalence of this malaise. Nations in Sub-Saharan Africa, South Asia and Latin America are currently with the highest level of poverty and consequently with the lowest level of socioeconomic development, violence, and unrest and generally unacceptable low standard of living. Out of the world population of 7.7 billion people, more than 1.5 billion people are poor and live below the poverty line of less than one dollar per day. Out of this figure Africa alone accounts for 555 million people. In Nigeria, more than 100 million people from the country's estimated population of 200 million are living in abject poverty (Vanguard News, October 18, 2016).

The incidence of poverty in Nigeria is growing day by day as evidenced in the figures released by the National Bureau of Statistics; that about 100 million Nigerians are said to be living below 1 dollar a day. The Bureau's statistics on poverty on October 18, 2016 stated that 112 million Nigerians representing $67.1 \%$ of the country's population are living in absolute poverty (Vanguard News, October 18, 2016).

Poverty has remained one of the most serious problems in Nigeria today and is widespread in rural communities where more than half of the country's population resides. People do not have access to good food, clothing, shelter, sanitation facilities, pipe-borne water, education, good healthcare etc. Despite various efforts of the government from independence to date to combat poverty, it has been on the increase. Nigeria's proportion of the poor has doubled over the last two decades, during which time the country received more than $\$ 3000$ billion in oil and gas revenue. Indeed, it is a paradox of poor people in rich countries, in other words "poverty in the midst of plenty". Statistical data available indicates that by 1960 the poverty level in Nigeria covers about $15 \%$ of the population and by 1980 it rose to $28 \%$. In 1985, the poverty level was $46 \%$ and dropped to $43 \%$ by 1992. By 1996, the Federal Office of Statistics estimated the poverty level in Nigeria at about 66\% (Oyemomi, 2003). As at June 2019, 91.8m Nigerians were living in extreme poverty (Saharareporters.com, June 5, 2019).

The high level of poverty in Nigeria, which has attained an endemic nature, is worrisome. Poverty has made Nigeria attain an unenviable status as one of the poorest countries in the world, such that no government (no matter the level), organization, community, clan or family can survive effectively without introducing one kind of poverty reduction strategy or the other. The problem is essentially not that of programmes and strategies so adapted in poverty reduction efforts. Nigeria has not been known to lack in such efforts; yet she is still ranked among the world's poorest nations. One out of two Nigerians is in poverty and it is becoming dynastical, that is, children of the poor are likely to become poor due to widening gap in access to quality education (Ibrahaim, 2015). Recently Nigeria has been declared to have become the headquarters of world poverty having overtaken India.

\section{The Concept of Poverty}

Poverty, like most concepts, is not easily amenable to a straightforward definition. It has been defined by various authors in different ways. Agbiokoro (2010), looked at poverty as a condition in which an individual or a group of individuals or community are unable to meet their basic 
material needs such as foods, potable water, clothing, shelter, basic health care, education, lack of participation in the prevailing social standard of living, dignity and having limited chance of advancing their welfare just to the limit of their capabilities.

Poverty is hunger, poverty is lack of shelter, poverty is being sick and not being able to see a doctor. Poverty is not having access to school and not knowing how to read. Poverty is not having a job, is fear for the future, living one day at a time. Poverty is losing a child to illness brought about by unclean water. Poverty is powerlessness, lack of representation and freedom. Poverty is a state of being without resources across a wide range of circumstances (Aidelunuoghene, 2014).

The United Nations Aidelunuoghene (2014) sees poverty as a denial of choices and opportunities, a violation of human dignity. It means a lack of basic capacity to participate effectively in society. It means not having enough to feed and clothe a family, not having a school or clinic to go to, not having the land in which to grow one's food or job to earn one's living, not having access to credit. It means insecurity, powerlessness and exclusion of individuals, households and communities. It means susceptibility to violence, and it often implies living in marginal or fragile environments, without access to clean water or sanitation. According to the World Bank, poverty is pronounced deprivation in well-being, and comprises many dimensions. It includes low incomes and the inability to acquire the basic goods and services necessary for survival with dignity. Furthermore, the World Bank sees poverty encompassing low levels of health and education, poor access to clean water and sanitation, inadequate physical security, lack of voice and insufficient capacity and opportunity to better our lives.

Poverty could denote a state of deprivation as was captured by Nigeria's Federal Ministry of Economic Co-operation and Development (1992:3) as "not having enough to eat, a high rate of infant mortality, a low life expectancy, low educational opportunities, poor water, inadequate health care, unfit housing and a lack of active participation in the decision making process". It could also denote absence or lack of basic necessities of life or lack of command over basic consumption needs such as food, clothing and or shelter, glaring defects in the economy, etc (Oyemomi, 2003). The Central Bank of Nigeria (1999:1) views poverty as: a state where an individual is not able to cater adequately for his or her basic needs of foods, clothing and shelter; is unable to meet social and economic obligations, lacks gainful employment, skills, assets and self-esteem; and has limited access to social and economic infrastructure such as education, health, portable water, sanitation and consequently has limited chance of advancing his or her welfare to the limit of his or her capabilities.

Marshal (1998:516), poverty is defined as "a state in which resources, usually material but sometimes cultural, are lacking and could be delineated into two broad categories of "absolute and relative" terms. Absolute poverty refers to "a state in which an individual lacks the resources necessary for subsistence" while the relative definitions refer to the individual's or groups' lack of resources when compared with that of other members of the society". 


\section{POVERTY REDUCTION INITIATIVES IN NIGERIA}

Because of the menace and devastating effects of poverty in Nigeria, no Nigerian Government, be it military or civilian has come without introducing and leaving behind one form of poverty alleviation or reduction programme meant to reduce the level of poverty, give hope and succor to the poor and, or move towards some sort of wealth creation for the overall goal of rural development of the nation. Strategies, policies and plans were articulated; programmes and projects were formulated and executed over the years. Successive Governments in Nigeria since independence have embarked on various programmes aimed at tackling poverty in the country, yet the war against poverty in Nigeria seems to be an unending one.

Ayo, (2012) in (Abdu, 1992), (Afolabi, 1999), mentioned the following among others as some of the various poverty reduction programmes the Nigerian government has embarked upon at different times for the purpose of rural development, they include:

\section{Better Life for Rural Women}

The Better Life Programme was mostly gender specific; it was meant to improve the life of rural women. The programme was initiated by the late Maryam Babangida. Harnessing the potentials of the rural women in order to boost their economic activities and improving their incomes were the goals of the programme.

However, the programme was hijacked by position-seeking individuals. The resources were used for personal aggrandizement rather than pragmatic in its objectives. Family Support Programme (FSP), the successor of Better Life for Rural Women, was beset by the same problems suffered by its predecessor, and therefore, could not achieve its objectives.

\section{Directorate of Food, Roads, and Rural Infrastructure (DFRRI)}

The establishment of DFRRI in 1986 by the Federal Military Government was intended to bring development to the rural areas where over $70 \%$ of Nigerian population resides and works primarily as farmers. It was initially funded with savings from petroleum subsidy reduction which was estimated to yield a total of about N900m in 1986.

\section{People's Bank of Nigeria (PBN)}

The Peoples Bank of Nigeria (PBN) was another effort of the Nigerian Government to promote rural financial intermediation with the objective of tackling poverty and promoting rural development. In fact, the government had come to the realization that the increasing pauperization of the micro-entrepreneurs, mostly rural dwellers and women, was lowering the standard of living of the people.

Policy makers and commentators also recognized that this group of people lacked the collateral that could secure them the loans that are usually obtained through conventional commercial banks. The enabling law specifically charged the bank to meet the credit needs of small borrowers who cannot satisfy the stringent collateral requirements normally demanded by conventional banks. 


\section{Family Economic Advancement Programme (FEAP)}

FEAP was established in 1997. It was meant to address the various problems associated with the utilization of the abundant natural resources in the rural areas. These problems include postharvest cost of agricultural output, inappropriate conservation techniques and an accessibility of rural communities to market. FEAP was established to achieve among others, the utilization of all available resources for the benefit of Nigerians through improved production, storage preservation, processing, recycling, packaging and marketing and as well as the improvement of the living standard of the people.

\section{National Directorate of Employment (NDE)}

The National Directorate of Employment (NDE) was established in 1986 by the then Military regime of General Ibrahim Babangida to tackle the problem of mass unemployment. Specifically, the directorate gave loans, trained the unemployed and assisted small-scale

entrepreneurs in various ways. The National Directorate of Employment, at creation was given the following mandate: To

i. Design and implement programmes to combat mass unemployment in Nigeria;

ii. Articulate policies aimed at developing work programmes with labour intensive potentials;

iii. Obtain and maintain a data bank on employment and vacancies with a view to acting as a clearing house to link job seekers with vacancies in collaboration with other agencies; and

iv. Implement any other policies as may be laid down from time to time by the board established under the enabling Act.

\section{The National Accelerated Food Production Programme (NAFPP)}

The National Accelerated Food Production Programme (NAFPP) was launched by the Federal Government in 1972 and was the first major attempt by the government to promote agricultural development at the farmer's level in Nigeria. The programme was implemented at the field level mainly by the state extension workers. The aim of the programme was to accelerate the production of high-yield varieties such as rice, maize, guinea-corn, millet, wheat, cassava and cowpea through the introduction of insecticides, herbicides, high-yielding seeds, fertilizers, credit facilities, marketing and storage facilities for produce in order to achieve food selfsufficiency.

\section{The National Agricultural Land Development Authority (NALDA)}

The failure of the agricultural development strategies resulted in the creation of a vast pool of unemployment and marginally men and women of Nigeria's rural majority with the consequent underutilization of our abundant land and other physical resources. The National Agricultural Land Development Authority (NALDA) was established in 1991 with the goal of ensuring the optimal use of the nation's land and human resources to uplift the quality of rural life. 


\section{Agricultural Development Programme (ADP)}

Agricultural Development Programme (ADP) is a World Bank-assisted programme. It was executed jointly by the World Bank, the Federal and State Governments. Its principal aim was to boost the productivity of the peasant farmers through farm inputs, supply extension services and construction and maintenance of rural roads. The achievement of APD was quite sizable. It taught farmers modern techniques of farming as well as supply of necessary farm implements and practiced the research output of various agricultural research institutions through pilot farms.

\section{Agricultural Credit Guarantee Scheme Fund (ACGSF) and Rural Banking Scheme}

In order to encourage banks to meet the target set for commercial and merchant banks by the Central Bank of Nigeria as regards their loan portfolio that must be channeled to agriculture, the Federal Government established the Agricultural Credit Guarantee Scheme Fund in 1977. Under the scheme, the ACGSF provides up to $75 \%$ level of guarantee to defaulting farmers. This is because of the reluctance of the banks to extend credit to farmers on account of the high default rate. The scheme guarantees loans to individuals, to a limit of N50,000.00 while for companies, co-operatives, organizations and other corporate bodies, the minimum is N1,000,000.00. In addition, the Federal Government introduced the Rural Banking Scheme (RBS). The primary aim of the rural banking scheme was to develop rural banking habits.

\section{Operation Feed the Nation (OFN) and Green Revolution}

The Operation Feed the Nation (OFN) was essentially a political programme for the mobilization of the teeming population for the attainment of high agricultural production and

better agricultural practices. It was a special programme instituted by the Military Government and consequently not rooted in the Third national Plan, which was being implemented at that time of its launching. This is one of the principal failures of the programme, among other reasons.

The Green Revolution in Nigeria, unlike the movement in other parts of the world, was actually a change of nomenclature from the OFN; it was therefore short-lived and suffered similar circumstances. In a nutshell, the Green Revolution Programme, like its predecessor, the OFN, suffered from rather disjointed, short-term and ad-hoc planning, which made no serious impact on either the agricultural sector in particular and the rural sector in general.

\section{Department of Rural Development}

The specific role of the Federal Government is to define national policy and ensure that all relevant agencies work harmoniously and effectively towards the attainment of objectives. It has the responsibility to provide leadership, direction, support, coordination to the entire national rural development effort. In order to give priority attention and focus to this role, the government has strengthened the Department of Rural Development under the Federal Ministry of Agriculture and Rural Development. The principal mandate of the Department of Rural Development is to coordinate all rural development programmes in the country. 


\section{The National Poverty Eradication Programme (NAPEP)}

The National Poverty Eradication Programme (NAPEP) was set up in 2001 by Obasanjo's administration. NAPEP's goal was to train youths in vocational trades, to support internships, to support micro-credit among others. The National Poverty Eradication Programme (NAPEP) was set up mainly to streamline other previous strategies put in place in fighting poverty in Nigeria and then charged the agency with the co-ordination of various efforts by the government in poverty reduction and eradication.

The target of NAPEP was to completely wipe out poverty in Nigeria by the year 2010 . There were three stages to the realization of this ambitious target which have been identified as follows:

i. The first stage is the restoration of hope in the mass of poor people in Nigeria. This involves providing basic necessities to hitherto neglected people particularly in the rural areas.

ii. The second stage is the restoration of economic independence and confidence.

iii. The final stage is wealth creation.

\section{THE LIBYAN EXPERIENCE IN FIGHTING POVERTY}

Libya is a very small country in the world demographically, located in North Africa with a population size of six million eight hundred thousand people (Libya Population - 2020 Worldometer, 29 ${ }^{\text {th }}$ March, 2020). It is bordered by Egypt, Sudan, Chad, Niger, Algeria and Tunisia. Libya was a poor country during the reign of King Idris I and when Muammar Gaddafi took over power in 1969. The country was however, transformed into an enviable wealthy nation in Africa during the rule of Muammar Gaddafi which lasted for 42 years (1969 to 2011) where the Libyan citizens were provided free social welfare services till when he was killed during the Libyan War of 2011.

Libya became an independent State on December 24, 1951 after gaining its sovereignty from Turkey. On this day the United Libyan Kingdom was created under the rule of King Idris. King Idris was, however, overthrown by Colonel Muammar Gaddafi in a coup in 1969. After the overthrow, Gaddafi established the Libyan Arab Republic. Under the rule of Gaddafi, only the 1969 coup date was permitted to be marked.

At the time of independence, the Libyan economy was based mainly on agriculture, which was divided more or less evenly between field (including tree) crops and livestock products. Agriculture employed more than $70 \%$ of the labour force and contributed about $30 \%$ of the GDP, depending on climatic conditions. Libya had practically no industry and, given the limitations of the agricultural sector, could produce few exports to be exchanged for the import commodities the country needed. (Libya - Growth and structure of the economy. countrystudies.us/libya/58.htm). 
To the Libyan citizens, Libya was a paradise on earth during the rule of Muammar Gaddafi as almost everything they needed was provided free or subsidized. For over 40 years, Gaddafi promoted economic democracy and used the nationalized oil wealth to sustain progressive social welfare programmes for all Libyans. The following were some of the welfare programmes by the Gaddafi's government to the citizens (CNNiReport November 21, 2012):

i. There was no electricity bill in Libya, electricity was free for all its citizens.

ii. Loans were provided free to those who needed them, as there was no interest paid on them. Banks in Libya were state-owned and loans were given to all citizens at a $0 \%$ interest rate by law.

iii. Home was considered a human right in Libya. Gaddafi vowed that his parents would not get a house until everyone in Libya had a home.

iv. All newlyweds in Libya receive $\$ 50,000.00$ from the government to buy their first apartment.

v. Education and medical treatments were free in Libya. Before Gaddafi, only $25 \%$ of Libyans were literates, but during Gaddafi's rule the figure stood at $83 \%$.

vi. Libyans taking up farming as a career, they received farm land, a farming house, equipment, seeds and livestock to kick-start their farms- all for free.

vii. If Libyans cannot find the education or medical facility they needed in Libya, the government funded them to go abroad for it.

viii. In Gaddafi's Libya, if a Libyan buys a car, the government subsidized $50 \%$ of the price.

ix. The price of petrol in Libya was $\$ 0.14$ per litre.

x. If a Libyan is unable to get employment after graduation, the State would pay the average salary of the profession as if he or she is employed until employment is found.

xi. A portion of Libyan oil sale is credited directly to the bank accounts of all Libyan citizens.

xii. A mother who gave birth to a child under Gaddafi, received $\$ 5,000.00$ as child benefit upfront.

xiii. $\quad 40$ loaves of bread in Libya cost $\$ 0.15$.

xiv. $25 \%$ of Libyans had a university degree.

xv. Gaddafi carried out the world's largest irrigation project, known as the Great ManMade River Project, to make water readily available throughout the desert country. 


\section{RECOMMENDATIONS}

Despite various efforts and strategies by successive governments at all levels in Nigeria to fight and reduce poverty, poverty still persists and is always on the rise in the country. Available statistics show that more than half of Nigerian population resides in poverty, which means that every one out of two Nigerians is in poverty. Besides the Libyan experience, the following lines of recommendations are hereby given as antidotes for a successful fight in poverty reduction in Nigeria:

Government should provide free social services to the people whose cost should be captured in the country's yearly national budgets. The government no doubt can do this, considering the abundant revenue potentials the country has.

Another way the government can tackle poverty in the country is that the government should own special banks whose mandate would be to give credit facilities to those who need them for businesses. Such credit facilities should attract minimal interest rates of say not more than $3 \%$. Nigeria Bank of Industry and Nigeria Development Bank are good examples the government can use in this regard.

Government should provide cheap and free housing to the poor especially, the rural poor who cannot afford the cost of owning houses.

Government should encourage people to take to agriculture as a form of business which has a multiplier effect in generating employment and providing food for the nation. This the government can do by granting loans to the farmers at $0 \%$ interest rate. This can be done through the Nigeria Agricultural and Co-operative Bank.

Another area that the government can adopt in reducing poverty in the country is to invest massively on education. Education plays a major role in reducing poverty. It promotes economic growth, national productivity and innovation, and values of democracy and social cohesion. In Nigeria, the population with no education accounts for most of the poor. For example (Bakare, 2015) stated that 65 million Nigerians are illiterate. It is the opinion of this paper that the government should encourage the development of education in the country, and that education should be free from primary to secondary levels. The current educational system (6-3-3-4)in the country should be reviewed as it is now regarded as a failure because of its nonfunctionality compared to other countries in the world. The Nigerian educational system currently does not equip its products especially, at lower levels for self-employment.

Another way worthy of consideration for effective fighting against poverty in the country, is that citizens should endeavour to select honest and purposeful leadership in the country to provide good governance that would bring about massive infrastructural transformation that can lead to economic growth and development to generate employment and improve the country's GDP. Besides that, there should be an effective corruption fighting mechanism devoid of government interference as well as creating a peaceful atmosphere where people coexist harmoniously pursuing their economic activities. 


\section{REFERENCES}

Abang, P.O. (2015), Impact of Fadama II Project on Poverty Reduction: A Comparative Study of Imo, Ogun and Kaduna States, Nigeria, 2004 - 2009. A PhD Thesis submitted to the School of Postgraduate Studies, Ahmadu Bello University, Zaria

Aliy, A. (1999), Short and Medium Poverty Reduction Strategies in Nigeria, Abuja: Family Economic Advancement programme

Amangwai, J.M. (2019), Fadama III Projects and Rural Poverty Reduction in Nasarawa State, 2009-2013. A PhD Thesis submitted to the School of Postgraduate Studies, Nasarawa State University, Keffi, Nigeria

Ayo, M. (2012), Issues of Development and Poverty Reduction in Nigeria, Destiny Ventures Press, Km2, Gboko Road, Makurdi, Nigeria

Bakare, M. 2015. Nigerian Literacy Rate. Vanguard Newspapers, December 17

Central Bank of Nigeria (2003): An Appraisal of Federal Government NAPEP Bullion 27, January/March

Economic Structure of Libya. www.economywatch.com . Retrieved 5 May, 2020

Economy of Libya. https://en.m.wikipedia.org. Retrieved 29 April, 2020

Facts about Libya under Gaddafi You Probably Did Not Know About, CNNiReport, posted November 21, 2012

History of Libya Under Muammar Gaddafi. https://en.m.wikipedia.org. Retrieved 6 May, 2020

History of Libya. historyworld.net/wrld-his/Plain Text Histories Responsive. Retrieved 4 May, 2020

Ibrahim, C.Z. (2015), Challenges and Prospects of Poverty Alleviation Strategies in Nigeria: An Appraisal of the CCT in Select LGAs in Nasarawa State, unpublished research work

Libya-Growth and structure of the economy. countrystudies.us/Libya/58.htm. Retrieved 26 March, 2020

National Bureau of Statistics on Poverty (NBS), October 18, 2016

Oyemomi, E.O. (2003), An Assessment of Poverty Reduction Strategies in Nigeria (1983 2002), Being a Dissertation Submitted to the School of Postgraduate Studies of the St Clements University in Partial Fulfilment of the Requirements for the Award of the Doctor of Philosophy (Management)

Percentage of Globally Poor People Living in Africa, htt://borgenproject.org/10-quick-fastabout-poverty-in-africal. Retrieved May 2, 2020

Where is Libya? www.worldatlas.com/af/ly/where-is-libya.html. Retrieved 7 May, 2020 